\title{
Identification of Misconceptions in Science Learning During the Covid-19 Pandemic Using the CRI (Certainty of Response Index) Method for Primary school Students
}

\author{
Elisa Prezilia Dewi ${ }^{1}$, Fitria Wulandari ${ }^{*}$ \\ ${ }^{1}$ Primary School Teacher Education Study Program, Universitas Muhammadiyah Sidoarjo, Sidoarjo, Indonesia
}

DOI: $\underline{10.29303 / \text { ippipa.v7iSpecialIssue.876 }}$

\section{Article Info}

Received: August 13th, 2021

Revised: November 24th 2021

Accepted: December 1'st, 2021

\begin{abstract}
This research aims to identify the science misconceptions of elementary school students using CRI (Certainty of Response Index), as well as to describe the factors of students' misconceptions at Primary school Muhammadiyah 8 Tulangan. This research uses the descriptive qualitative method. The subjects used in this study were class $\mathrm{V}$, totaling 26 students. Data collection techniques using the test, interviews, and documentation. Based on the results obtained from the research as a whole, the highest misconception is about the concept of the effect of temperature on changes in the shape of objects by $44.70 \%$, the concept of temperature and heat by $39.42 \%$, and the lowest misconception is about the concept of object properties by $32.04 \%$. From the results of research using the CRI (Certainty of Response Index) method, several factors cause misconceptions, namely from the students themselves who come from the initial concept and students wrong intuition, then misconceptions from the teacher, as well as incomplete book explanations. So it can be concluded that science learning during the covid-19 pandemic caused misconceptions for students of Primary school Muhammadiyah 8 Tulangan.
\end{abstract}

Keywords: Misconceptions; Material Temperature and Heat; CRI (Certainty of Response Index) method

Citation: Dewi, E. P., \& Wulandari, F. (2021). Identification of Misconceptions in Science Learning During the Covid-19 Pandemic Using the CRI (Certainty of Response Index) Method for Primary school Students. Jurnal Penelitian Pendidikan IPA, 7(SpecialIssue), 145-150. https://doi.org/10.29303/ippipa.v7iSpecialIssue.876

\section{Introduction}

Education is an important aspect of developing and improving the quality of human resources. In the era of globalization, the aspect of education is one of the policies that must be considered in human development (Djuwarijah, 2008). Indonesia's human development through education is expected to provide provisions for the younger generation who can compete globally. The success of educational goals is largely determined by the curriculum that is held as a reference in learning activities (Doyan et al., 2020). Improving the quality of education with the implementation of the 2013 curriculum, although the change in the curriculum often causes debate among experts (Artapati \& Budiningsih, 2018).

One of the subjects in the 2013 curriculum in elementary schools is science learning. Learning science has an important contribution for students to run and overcome problems in everyday life (Basam et al., 2018). Learning science will teach students scientific ways of thinking (Laksana, 2016). Science learning in elementary schools is a form of developing students' abilities to provide thinking skills using scientific steps.

In science learning, one of the elements studies is the product element, where the product element is

\footnotetext{
*Email: fitriawulandari1@umsida.ac.id
} 
related to facts, theories, and law (Sayekti, 2019). The product element relates to the factual dimension, meaning that learning science cannot be separated from understanding science concepts scientifically. Learning science at the primary school level is more focused on the cultivation of basic concepts (Laeli et al., 2020). This view shows that learning science in elementary school places more emphasis on learning science concepts. Students' science concepts in the teaching and learning process can be seen by evaluating the results (Juliani et al., 2021). Understanding the nature of science is important to understand (Putri et al., 2021). The concepts of science are obtained through an experiment or experiment which is carried out based on scientific procedures (Susilawati et al., 2020). In learning science, it is hoped that the teacher does not only explain the concepts, but in learning science, the teacher must involve students in the scientific process (Sulthon, 2016). That is, in science learning activities, students understanding of concepts is obtained through scientific activities such as experiments, observations, analysis, investigations, and inferences, so that students gain a correct understanding of concepts so that students do not experience conceptual errors or what are called misconceptions.

Today, misconceptions are still one of the problems with learning science in elementary schools. Learning science in elementary schools is one of the subjects that has a high level of difficulty (Laeli et al., 2020). Furthermore, (Wulandari, 2016) said that learning science can make students think critically. Thus, science learning in elementary schools is taught at a high level of conceptual understanding. This will certainly have an impact on students' understanding of concepts because understanding the wrong concepts will cause students to have misconceptions. Based on research conducted by (Zayyinah et al., 2018) shows that students experience misconceptions in science learning $54,00 \%$ and understand concepts $15,33 \%$. This shows that the ability to understand students' concepts in science learning is still low and the misconceptions experienced by students are still high.

Misconceptions can be obtained by students from daily life experiences (Faizah, 2016) Misconceptions in science can be described as ideas from students' life experiences or unstructured informal education (Soeharto et al., 2019). Misconceptions can be caused by the initial concepts that students have, and rationally students build misconceptions, and it happens continuously (Sopiany \& Rahayu, 2019). Meanwhile, another opinion explains that there is one cause of misconceptions, including the initial concepts that students have, the learning carried out by the teacher, and the learning materials used (Yuliati, 2017). In science learning, if the teacher does not pay attention to the student's initial understanding of learning, the students will not get the correct understanding of the concept.

If a person's cognitive structure does not contain relevant concepts, then new information is processed through rote memorization (Laksana et al., 2017). This view shows that in the learning process, if the cognitive structure is not in accordance with the relevant concepts, then new knowledge or new information will not be stored in memory. This shows a concept error (misconception). Misconception will cause the understanding learned to not be stored by students in memory. Furthermore, (Yuliati, 2017) argues that misconceptions will have an impact on student learning outcomes.

At this time, the whole world is experiencing changes in learning due to the 2019 disease coronavirus pandemic, also called covid-19, causing learning that is carried out at school to be done at home or online. All levels of education have problems with online learning during the pandemic (Kusumawati et al., 2021). This, of course, will require teachers to teach science learning in elementary schools so that students do not experience misconceptions. Identification of students' misconceptions about science learning in elementary schools is needed. One method for identifying students' misconceptions is the CRI (Certainty of Response Index). The CRI method is used to detect whether students understand the concept, understand the concept but are not sure, do not understand the concept, and misconceptions. And CRI is used to measure the level of student confidence in the answers to the test given.

\section{Method}

The research method used is descriptive qualitative research to describe the science misconceptions of elementary school students using the CRI (Certainty of Response Index) and the factors that cause misconceptions in elementary school students. The research was carried out at Primary school Muhammadiyah 8 Tulangan in the academic year 2020/2021. The research was carried out from March 24 to April 2, 2021. The research subjects in this study were students of Primary school Muhammadiyah 8 Tulangan, a total of 26 students, consisting of 11 female students and 15 male students.

The research instrument used a test sheet instrument, an interview guide, and a documentation sheet. The test sheet given is in the form of an essay question with a total of 15 questions, where the science material is tested at temperature and heat material that has been equipped with the CRI (Certainty of Response Index) method. Then the interview questions were given in the form of questions regarding the concept of 
science learning in temperature and heat, as well as questions to be able to find out the factors that cause students to experience misconceptions. While the test documentation is used to check the student's essay test results.

The data validity technique in this study used triangulation. The type of triangulation used is technical triangulation. After the test using CRI (Certainty of Response Index) on the science learning material temperature and heat, they interviewed students and analyzed the results of the student's answer documents to questions relating to science learning material temperature and heat.

The data analysis technique used in this study is the Miles and Huberman model, where there are several stages, namely the data reduction, data display, and conclusion drawing or verification. As for reducing the results of students' test answers in the form of essay questions equipped with CRI, it is presented in table 1 for the CRI answer category developed by (Hakim et al., 2012), as follows.

Table 1. CRI Answer Categories

\begin{tabular}{llll}
\hline Answer & Reason & CRI Value & Category \\
\hline True & True & $>2.5$ & UC \\
True & True & $<2.5$ & UCBS \\
True & False & $>2.5$ & M \\
True & False & $<2.5$ & DUC \\
False & True & $>2.5$ & M \\
False & True & $<2.5$ & DUC \\
False & False & $>2.5$ & M \\
False & False & $<2.5$ & DUC \\
\hline
\end{tabular}

Information:

UC : Understand the Concept

UCBS : Understand the Concept But Not Sure

DUC : Don't Understand the Concept

M : Misconception

The calculate the percentage of students who experience misconceptions, do not understand the concept, understand the concept but are not sure, and understand the concept in each essay item, use the following formula.

$$
P=\frac{f}{n} x 100 \%
$$

\section{Result and Discussion}

Based on the results of the essay test equipped with CRI, which consist of 15 questions given to students, the results of interviews, and test documentation, it can be seen that the misconceptions in science learning consist of three concepts, namely the concept of temperature and heat, the concept of the properties of objects, and the concept of the effect of temperature on the shape of objects. The results of the misconceptions on the concepts of temperature and heat can be seen in Table 2 as follows.

Table 2. Percentage of Students with Misconceptions on Questions Number 1-4.

\begin{tabular}{llllll}
\hline Concept & $\begin{array}{l}\text { Question } \\
\text { Number }\end{array}$ & UC & UCBS & DUC & M \\
\hline Tempera & 1 & $38.46 \%$ & $0 \%$ & $42.30 \%$ & $19.23 \%$ \\
ture and & 2 & $34.16 \%$ & $0 \%$ & $34.61 \%$ & $30.76 \%$ \\
Heat & 3 & $15.38 \%$ & $0 \%$ & $26.92 \%$ & $57.69 \%$ \\
& 4 & $15.38 \%$ & $0 \%$ & $34.61 \%$ & $50 \%$ \\
Average & $25.84 \%$ & $0 \%$ & $34.61 \%$ & $39.42 \%$ \\
\hline
\end{tabular}

Based on table 2 above, shows that the average percentage of students experiencing misconceptions about the concept of temperature and heat with a higher percentage is $39.42 \%$ compared to students who understand the concept, understand the concept but are not sure, and do not understand the concept. So, in this concept, students still do not understand the concepts of temperature and heat correctly, students still have misconceptions about the concepts of temperature and heat by equating the meaning of temperature with heat, assuming that large objects always require high temperature, balloons placed on a burning candle will explode, and the temperature of the boiling water varies.

The misconceptions that occur in the concept of object properties, students experience the most misconceptions on question number 7 by $38.46 \%$. In this concept, students are given questions about the properties of solids, liquids, and gases. Based on the results of the test and students interviews, some students have misconceptions by assuming that solid objects can change shape, while liquid objects have a fixed shape if they are moved to different places, and gas objects can be seen. However, if viewed based on the percentage of table 3, most students are quite able to understand the concept of object properties. Data on the percentage of students' misconceptions on the concept of object properties can be seen in Table 3 as follows.

Table 3. Percentage of Students with Misconceptions on Questions Number 5-7.

\begin{tabular}{llllll}
\hline Concept & $\begin{array}{l}\text { Question } \\
\text { Number }\end{array}$ & UC & UCBS & DUC & M \\
\hline Prperties & 5 & $26.92 \%$ & $0 \%$ & $50 \%$ & $23.07 \%$ \\
of & 6 & $50 \%$ & $0 \%$ & $15.38 \%$ & $34.61 \%$ \\
Objects & 7 & $26.92 \%$ & $0 \%$ & $30.76 \%$ & $38.46 \%$ \\
\hline Average & $34.61 \%$ & $0 \%$ & $33.33 \%$ & $32.04 \%$ \\
\hline
\end{tabular}

Furthermore, the results of the essay test equipped with CRI, students interviews, and test documentation showed that students also had 
misconceptions about the concept of the effect of temperature on the shape of objects. The misconceptions that occur in students are high at $44.70 \%$ compared to students who understand the concept. Most students experience misconceptions on question number 15 (sublime object form). In the concepts tested through tests and interviews, students have not been able to distinguish between crystallized, sublimated, condensed, evaporated, frozen, and thawed objects. The data from students' misconceptions on the concept of the effect of temperature on the shape of objects can be seen in Table 4 as follows.

Table 4. Percentage of Students with Misconceptions on Questions Number 8-15.

\begin{tabular}{llllll}
\hline Concept & $\begin{array}{l}\text { Question } \\
\text { Number }\end{array}$ & UC & UCBS & DUC & M \\
\hline The effect of & 8 & $15.38 \%$ & $3.84 \%$ & $34.61 \%$ & $46.15 \%$ \\
temperature & 9 & $26.92 \%$ & $0 \%$ & $30.76 \%$ & $42.30 \%$ \\
on the shape & 10 & $15.38 \%$ & $3.84 \%$ & $30.76 \%$ & $53.84 \%$ \\
of an object & 11 & $38.46 \%$ & $0 \%$ & $15.38 \%$ & $42.30 \%$ \\
& 12 & $30.76 \%$ & $0 \%$ & $26.92 \%$ & $42.30 \%$ \\
& 13 & $34.16 \%$ & $0 \%$ & $42.30 \%$ & $23.07 \%$ \\
& 14 & $15.38 \%$ & $7.69 \%$ & $46.15 \%$ & $38.46 \%$ \\
& 15 & $7.69 \%$ & $0 \%$ & $26.92 \%$ & $65.38 \%$ \\
\hline Average & & $23.49 \%$ & $5.12 \%$ & $31.66 \%$ & $44.70 \%$ \\
\hline
\end{tabular}

Based on tables 1, 2, and 3, it can be seen that the misconceptions that occur in students with a high percentage are in the concept of the effect of temperature on the shape of objects by $44.70 \%$, while the misconceptions that are classified as low are in the concept of object properties by $32.04 \%$.

This shows that misconceptions are still a problem in science learning. As in the research conducted by (Sofianto \& Irawati, 2020), it was also found that students had misconceptions about temperature and heat. Therefore, teaching science to students can be done with meaningful learning. Meaningful learning can occur if the new information received by students at the time of learning is closely related to existing concepts or received by previous students and will be stored in the cognitive structure (Panen, 2018).

Factors that cause students misconceptions come from students, teachers, and books. Based on the results of interviews with students, the cause of misconceptions comes from students because students have preconceptions or students' initial concepts are wrong and their intuition is wrong. It comes from the daily life of students before acquiring new concepts from the formal bench. Furthermore, students' intuitive thinking is wrong because students' observations of an object or event continuously make students thoughts spontaneously express their ideas without thinking objectively (Suparno, 2013).
Furthermore, the cause of the misconception that came from the teacher was because, during the covid19 pandemic, learning was carried out online, so students rarely do experiments, especially on temperature and heat, so students only delivered material. In addition, during the covid-19 pandemic, students were only given assignments by the teacher, the selection of inappropriate methods for delivering material during online learning, and the lack of use of media, so that students understanding of the material was less than optimal and caused students to experience misconceptions in science learning about temperature and heat.

The cause of students' misconceptions is also from the use by students. One of the causes of the incomplete explanation in the book and the use of difficult language, so that students experience misconceptions because students during the covid-19 pandemic are asked to understand the material without receiving the teacher's explanation directly at school. In addition, in the book used by students on temperature and heat, there is a concept map that is not equipped with a clear explanation. If there are is an incomplete explanation in the book, it can lead to big misconceptions. As a result, students only catch some of the material or don't understand it at all.

\section{Conclusion}

Science learning during the covid-19 pandemic caused misconceptions in class V students of Primary school Muhammadiyah 8 Tulangan. The misconceptions that occur in the concept of temperature and heat are $39.42 \%$, the concept of object properties is $32.04 \%$, and the concept of the effect of temperature on the shape of objects is $44.70 \%$. Factors that cause misconceptions come from students, teachers, and books.

\section{Acknowledgments}

The author would like to thank the supervisors and all friends who have helped the completion of this research.

\section{References}

Artapati, L. W., \& Budiningsih, C. A. (2018). Pelaksanaan pembelajaran Kurikulum 2013 di SD Negeri Serayu Yogyakarta. Jurnal Inovasi Teknologi Pendidikan, 4(2), 185-200. doi: https://doi.org/10.21831/jitp.v4i2.13016 [Indonesian]

Basam, F., Rusilowati, A., \& Ridlo, S. (2018). Profil Kompetensi Sains Siswa dalam Pembelajaran Literasi Sains Berpendekatan Inkuiri Saintifik. 
Pancasakti Science Education Journal, 3(1), 1. doi: https://doi.org/10.24905/psej.v3i1.800

[Indonesian]

Djuwarijah, D. (2008). Peningkatan Kualitas Sumber Daya Manusia Melalui Pendidikan Islam. Jurnal Pendidikan Islam, 1(1), 13-26. doi: https://doi.org/10.20885/tarbawi.vol1.iss1.art2 [Indonesian]

Doyan, A., Susilawati, S., \& Hardiyansyah, H. (2020). Development of Natural Science Learning Tools with Guided Inquiry Model Assisted by Real Media to Improve Students' Scientific Creativity and Science Process Skills. Jurnal Penelitian Pendidikan IPA, 7(1), $15 . \quad$ doi: https://doi.org/10.29303/jppipa.v7i1.485

Faizah, K. (2016). Miskonsepsi Dalam Pembelajaran Ipa. Jurnal Pendidikan Komunikasi dan Pemikiran Hukum Islam, 8(1), 115-128. doi: https://doi.org/10.31219/osf.io/spm84 [Indonesian]

Hakim, A., Liliasari, \& Kadarohman, A. (2012). Student Concept Understanding of Natural Products Chemistry in Primary and Secondary Metabolites Using the Data Collecting Technique of Modified CRI. International Online Journal of Educational Sciences, 4(3), 544-553. Retrieved from: https://iojes.net/?mod=makale_tr_ozet\&makale_ $\mathrm{id}=41174$

Juliani, J., Yusrizal, Y., \& Huda, I. (2021). Development of Four Tier Multiple Choice Diagnostic Tests to Know Students' Misconceptions in Science Learning. Jurnal Penelitian Pendidikan IPA, 7(4), 763-769. doi:

https://doi.org/10.29303/jppipa.v7i4.854

Sayekti, I. C. (2019). Analisis Hakikat Ipa Pada Buku Siswa Kelas Iv Sub Tema I Tema 3 Kurikulum 2013. Profesi Pendidikan Dasar, 1(2), 129-144. https://doi.org/10.23917/ppd.v1i2.9256

[Indonesian]

Kusumawati, L., Widodo, A., \& Rochintaniawati, D. (2021). Group Dynamics and Student Self-Efficacy in Online Science Learning during the COVID-19 Pandemic. Jurnal Penelitian Pendidikan IPA, 7(4), 568-575. doi: https://doi.org/10.29303/ippipa.v7i4.760

Laeli, C. M. H., Gunarhadi, \& Muzzazinah. (2020). Misconception of Science Learning in Primary School Students. Journal Education And Humanities Research, 397(1), 657-671. doi: https://doi.org/10.2991/assehr.k.200129.083

Laksana, D. N. L. (2016). Miskonsepsi Dalam Materi Ipa Sekolah Dasar. Jurnal Pendidikan Indonesia, 5(2), 166. doi: https://doi.org/10.23887/jpiundiksha.v5i28588 [Indonesian]

Laksana, D. N. L., Degeng, I. N. S., \& Dasna, I. W.
(2017). Why Teachers Faces Misconception: A Study Toward Natural Science Teachers In Primary Schools. European Journal of Education Studies, 3(7), 667-679. doi: https://doi.org/10.5281/zenodo.835198

Putri, D. S., Pramswari, L. P., Suryana, S. I., \& Widodo, A. (2021). Analysis of the Nature of Science in Elementary School Science Curriculum and Its Empowerment in Student Book. Jurnal Penelitian Pendidikan IPA, 7(3), 488-495. doi: https://doi.org/10.29303/ippipa.v7i3.763

Soeharto, Csapó, B., Sarimanah, E., Dewi, F. I., \& Sabri, T. (2019). A review of students' common misconceptions in science and their diagnostic assessment tools. Jurnal Pendidikan IPA Indonesia, 8(2), 247-266. doi: https://doi.org/10.15294/jpii.v8i2.18649

Sofianto, E. W. N., \& Irawati, R. K. (2020). Upaya Meremediasi Konsep Fisika pada Materi Suhu dan Kalor. Southeast Asian Journal of Islamic Education, 2(2), 107-120. doi: https://doi.org/10.21093/sajie.v2i2.2188

Sopiany, H. N., \& Rahayu, W. (2019). Analisis Miskonsepsi Siswa Ditinjau Dari Teori Kontruktivisme Pada Materi Segiempat. Jurnal Pendidikan Matematika, 13(2), 185-200. doi: https://doi.org/10.22342/jpm.13.2.6773.185-200 [Indonesian]

Sulthon. (2016). Pembelajaran IPA yang Efektif dan Menyenangkan bagi Siswa MI. Elementary: Islamic Teacher Journal, 4(1), 38-54. doi: https://doi.org/10.21043/elementary.v4i1.1969 [Indonesian]

Susilawati, S., Doyan, A., Artayasa, P., Soeprianto, H., \& Harjono, A. (2020). Analysis of Validation Development Science Learning Tools using Guided Inquiry Model Assisted by Real Media to Improve the Understanding Concepts and Science Process Skills of Students. Jurnal Penelitian Pendidikan IPA, 7(1), 41 . doi: https://doi.org/10.29303/jppipa.v7i1.473

Wulandari, F. (2016). Penerapan Model Pembelajaran Inkuiri Terbimbing untuk Meningkatkan Hasil Belajar IPA Siswa Sekolah Dasar. Pedagogia: Jurnal Pendidikan, 5(2), 267. doi: https://doi.org/10.21070/pedagogia.v5i2.259 [Indonesian]

Yuliati, Y. (2017). Miskonsepsi Siswa Pada Pembelajaran IPA Serta Remediasinya. Jurnal Bio Education, 2, 50-58. doi: http://dx.doi.org/10.31949/be.v2i2.1197 [Indonesian]

Zayyinah, Munawaroh, F., \& Rosidi, I. (2018). Identifikasi Miskonsepsi Siswa SMP dengan Certainty of Response Index (CRI) pada Konsep 
Suhu dan Kalor. Journal Science Education National

Conference, 2(1), 78-89 Retrieved from:

https://journal.trunojoyo.ac.id/nser/article/vie

$\underline{\mathrm{w} / 4795}$ [Indonesian] 